\title{
Impact of Land Reclamation on Acid Sulfate Soil and Its Mitigation
}

\author{
Arthanur Rifqi Hidayat ${ }^{1 *}$ and Arifin Fahmi $^{1}$ \\ ${ }^{1}$ Balai Penelitian Pertanian Lahan Rawa, Banjarbaru, South Kalimantan, Indonesia
}

\begin{abstract}
Land reclamation on acid sulfate soil is a process of improving acid sulfate soil to make them suitable for more productive use, such as increasing crop production. These efforts (land clearing and management, as well as water management system) on acid sulfate soils had increased sulfidic material oxidation, followed by soil acidification, the rise of toxic metal solubility, and basic cation leaching. Mitigation efforts are required to prevent these impacts such as proper water management, utilization of organic matter, adaptive varieties, and optimized technology of fertilization. These mitigations must be carefully done so that they have a minimum negative impact on soil and crop.
\end{abstract}

\section{Introduction}

Agriculture management for acid sulfate soil was quite difficult for farmers due to its low fertility level. Acid sulfate soil has low soil $\mathrm{pH}$, less than 3.5 [1]. Besides that, acid sulfate soil can be characterized by one or several things, such as jarosite appearance. This paper explains the impacts of land reclamation on acid sulfate soil and some efforts to minimize its negative impact. It reviews several data from previous studies in acid sulfate soil in Indonesia and other regions. Some of the data are redrawn and modified to describe other meanings more clearly, aside from explanation in the main papers.

\subsection{Characteristic of Acid Sulfate Soil's Properties}

Acid sulfate soil is defined as soil or sediment that contains iron sulfide. It can be affected by monosulfide or sulfuric materials. Acid sulfate soil has very low soil $\mathrm{pH}(2.5$ - 3.5), low nutrient, and base saturation (Table 1), and it contains toxic materials such as Aluminum (Al) and iron $(\mathrm{Fe})$ if the concentration is too high in soil [2]. High Aluminum's and iron's content affected the availability of Phosphor (P), and other nutrients such as Calcium (Ca), Potassium (K), and Magnesium, in acid sulfate soil. During the process of acid sulfate soil's formation, these ions are leached or washed out in the form of bonding with sulfate. As a result, aluminum's and irons ions saturated the exchange sites. Levels and solubility from each nutrient are affected by parent materials and hydrological conditions of the land so that every land has very much difference.

The hydrological condition of the land is the main factor to decides the dynamics of chemical properties in acid sulfate soil. Land inundation in swampland caused redox conditions, followed by iron and manganese reduction [4]. The dynamics of chemical properties in acid sulfate soil is also naturally affected by tidal wave (from sea or river) or seasonal ups and downs of groundwater level, so that soil characteristics as if forming seasonal cycle $[5,6]$, shown in Fig. 1. This matter is related to oxidation and sedimentation in the dry season followed by the reduction process and dissolution process from oxidation in the wet season, as well as solubility and partial pressure from carbon dioxide $[7,8]$.

Table 1. Physical and Chemical Characteristics of Acid Sulfate Soil in Kalimantan

\begin{tabular}{|c|c|c|c|c|}
\hline \multirow[b]{2}{*}{$\begin{array}{c}\text { Soil's } \\
\text { Characteristics a }\end{array}$} & \multicolumn{2}{|c|}{$\begin{array}{l}\text { Potential Acid } \\
\text { Sulfate }\end{array}$} & \multicolumn{2}{|c|}{$\begin{array}{c}\text { Actual Acid } \\
\text { Sulfate }\end{array}$} \\
\hline & $\begin{array}{l}\text { Upper } \\
\text { Layer } \\
(0-50 \\
\mathrm{cm})\end{array}$ & $\begin{array}{c}\text { Lower } \\
\text { Layer } \\
(50-200 \\
\mathrm{cm})\end{array}$ & $\begin{array}{c}\text { Upper } \\
\text { Layer } \\
(0-50 \\
\mathrm{cm})\end{array}$ & $\begin{array}{c}\text { Lower } \\
\text { Layer } \\
(50-200 \\
\mathrm{cm})\end{array}$ \\
\hline Soil Texture & $\begin{array}{c}\text { Silt } \\
\text { Clay } \\
(\mathrm{SiC})\end{array}$ & $\begin{array}{l}\text { Clay } \\
\text { (C) }\end{array}$ & $\begin{array}{l}\text { Silt } \\
\text { Clay } \\
\text { (SiC) }\end{array}$ & $\begin{array}{l}\text { Clay } \\
\text { (C) }\end{array}$ \\
\hline $\mathrm{pH} \mathrm{H} \mathrm{H}_{2} \mathrm{O}(1: 5)$ & 4.3 & 3.5 & 3.6 & 2.8 \\
\hline $\mathrm{EC}(1: 5)(\mathrm{dS} / \mathrm{m})$ & 7.25 & 7.32 & 5.69 & 4.34 \\
\hline C-organic (\%) & 9.16 & 6.61 & 10.93 & 7.51 \\
\hline N-total (\%) & 0.59 & 0.28 & 0.49 & 0.22 \\
\hline $\begin{array}{ll}\mathrm{P}_{2} \mathrm{O}_{5} & \mathrm{HCl} \\
(\mathrm{mg} / 100 \mathrm{~g}) & \end{array}$ & 115 & 33 & 45 & 17 \\
\hline $\mathrm{K}_{2} \mathrm{O} \mathrm{HCl}(\mathrm{mg} / 100$ & 32 & 29 & 81 & 73 \\
\hline 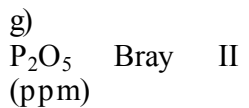 & 17.7 & 15.2 & 19.3 & 12.6 \\
\hline $\begin{array}{l}\text { Exchangeable } \mathrm{Ca} \\
(\mathrm{cmol} / \mathrm{kg} \text { soil })\end{array}$ & 5.11 & 4.61 & 4.12 & 3.49 \\
\hline $\begin{array}{l}\text { Exchangeable } \mathrm{Mg} \\
(\mathrm{cmol} / \mathrm{kg} \text { soil) }\end{array}$ & 7.05 & 8.02 & 9.25 & 8.30 \\
\hline $\begin{array}{l}\text { Exchangeable } \mathrm{K} \\
\text { (cmol/kg soil) }\end{array}$ & 0.56 & 0.43 & 0.89 & 0.37 \\
\hline $\begin{array}{l}\text { Exchangeable } \mathrm{Na} \\
\text { (cmol/kg soil) }\end{array}$ & 6.01 & 4.91 & 14.87 & 9.70 \\
\hline $\begin{array}{l}\text { KTK pH } 7 \\
\text { (cmol/kg soil) }\end{array}$ & 31.5 & 28.9 & 37.2 & 33.5 \\
\hline $\begin{array}{l}\text { Base saturation } \\
(\%)\end{array}$ & 49 & 55 & 42 & 40 \\
\hline Al saturation (\%) & 35 & 47 & 71 & 67 \\
\hline Pyrite $(\%)$ & 1.12 & 1.35 & 1.07 & 2.38 \\
\hline
\end{tabular}

${ }^{\mathrm{a}}$ Average value from 27 soil samples [3] 


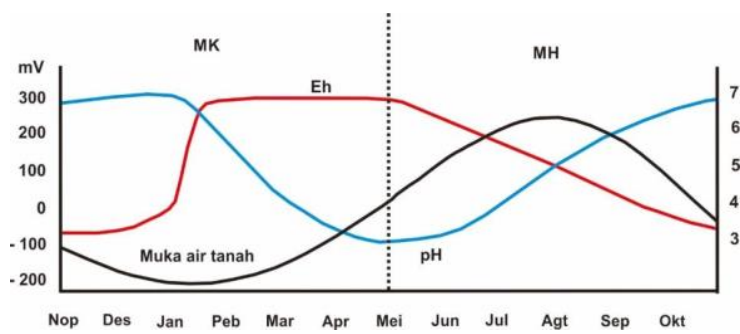

Figure 1. Dynamic patterns of $\mathrm{pH}$, Redox potential (Eh), and groundwater level, in dry (MK) and wet (MH) season. Location: Acid sulfate Soil in Vietnam [5].

\section{Impacts of Land Reclamation On Characteristic of Acid Sulfate Soil}

Reclamation comes from English vocabulary, to reclaim, which means to repair something that has been damaged. Based on the agronomical and land resources aspect, the reclamation of acid sulfate soil means land clearing, land management, water system management. The purpose of the reclamation of acid sulfate soil is to improve land function, especially, land productivity. In agriculture terminology, land managements aim to get the proportional area between rice cropping area and other crops as well as to easily manage agricultural resources from every aspect.

Efforts to reclaim the acid sulfate soil have the potential to impact the environment and not meet expectations. Reclamation causes changes in soil chemical properties that harm plant growth. This is related to the potential acidity and poisoning of metals and other potentially toxic substances such as $\mathrm{Fe}^{2+}$, $\mathrm{Mn}^{2+}, \mathrm{CO}_{2}$, dan $\mathrm{SO}_{4}{ }^{2-}$. thus, every action in the effort to reclaim acid sulfate soils must be calculated accurately and carefully. The principles of management of acid sulfate soils [9] based on priority are:

1. Disturbance to the soil must be minimized.

2. The oxidation of sulfidic material must be prevented.

3. If oxidation of sulfidic material has already occurred, it is important to decrease its oxidation rate. Or localize it, followed by special treatments.

4. Special treatment in drainage water to decreasing the negative impacts.

5. Addition of neutralizing acidity material.

6. Sulfidic materials in the soil must be managed carefully.

7. Planning and developing control system.

Constructions of water drainage in land reclamation caused the groundwater levels to decrease, thus causing the pedogenesis process to progress faster in stages. Soil layers containing pyrite will be oxidized, producing sulfuric materials such as jarosite. This process changed acid sulfate soil's status from potential to actual. These changes can occur briefly after the reclamation is done. This condition will continue to occur for a long time if there is no land mitigation. Changes in soil properties will be described in more detail in the explanation below.

\subsection{Soil Acidity}

Naturally, soil $\mathrm{pH}$ in acid sulfate soil is observed throughout the year will form a repeating pattern every year as reported by [5]. Land clearing which then followed by the construction of drainage or irrigation can cause exposure to a layer of pyrite minerals, encourage the oxidation of these materials, thus causing the decrease of soil $\mathrm{pH}$, especially in the early times of land reclamation. a decrease in soil $\mathrm{pH}$ due to acid sulfate land reclamation occurs around the Mekong River plain [6], as well as in Central Kalimantan (Fig. 2) [10]. During the reclamation process, large amounts of acid substances are continuing to produced and carried the surrounding waters even after five years of reclamation [11].

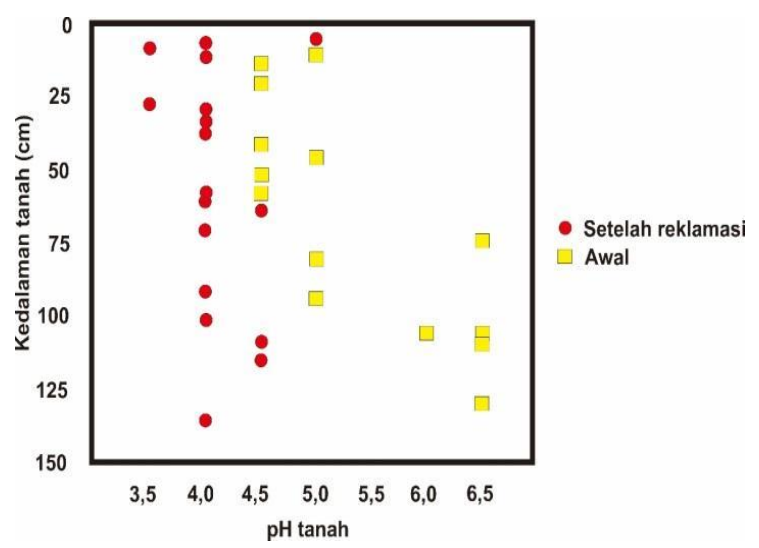

Figure 2. Change of soil $\mathrm{pH}$ in acid sulfate soil due to land reclamation [10].

\subsection{Dynamics of $\mathrm{Fe}^{2+}$ Solubility}

Constructions of drainage and irrigation water system in land reclamation caused pyrite to oxidized so that the concentration decrease [10]. These occurred due to oxidized process by either Oxygen or $\mathrm{Fe}^{3+}$ ion. $\mathrm{Fe}^{3+}$ ion had very high solubility at very low soil $\mathrm{pH}$. The chemical reaction that describes the oxidation process of pyrite by oxygen can be illustrated in the following equation:

$$
\begin{gathered}
2 \mathrm{FeS}_{2}+7 \mathrm{O}_{2}+2 \mathrm{H}_{2} \mathrm{O} \Rightarrow 2 \mathrm{Fe}^{2+}+4 \mathrm{SO}_{4}{ }^{2-}+4 \mathrm{H}^{+} \\
\mathrm{FeS}_{2}+14 \mathrm{Fe}^{3+}+8 \mathrm{H}_{2} \mathrm{O} \Rightarrow 15 \mathrm{Fe}^{2+}+2 \mathrm{SO}_{4}{ }^{2-}+16 \mathrm{H}^{+}
\end{gathered}
$$

Generally, Indonesia has two seasons, wet and dry season. Seasonal differences have a direct impact on groundwater and tidal water levels in the area around rivers. Acid sulfate soil which affected by this hydrological condition directly will have a fluctuating iron level. The geochemical pattern of Fe follows the hydrological conditions of the land [12]. In acid sulfate soil where its soil moisture increases, Ferro $\left(\mathrm{Fe}^{2+}\right)$ concentrations can reach $0.07-6600 \mathrm{mg} \mathrm{kg}^{-1}$ [13]. The highest solubility of $\mathrm{Fe}^{2+}$ in the soil occurred about two months after the rainy season, then gradually decreased, and relatively low solubility occurred in the dry season [5]. The increase in $\mathrm{Fe}^{2+}$ solubility is in line with the reduction in the redox potential of the soil due to the elevation of the groundwater level or some of the soil 
that has experienced flooding. Land reclamation followed by the construction of water irrigation + drainage in rice cropping causes changes in the solubility pattern of $\mathrm{Fe}^{2+}$. One - way water management system (TA) causes a typical solubility pattern of $\mathrm{Fe}^{2+}$ when compared to natural condition (A), shown in Fig. 3. One - way water management system used in this term is an effort to flood the land for a certain period and then dump the water outside the land.

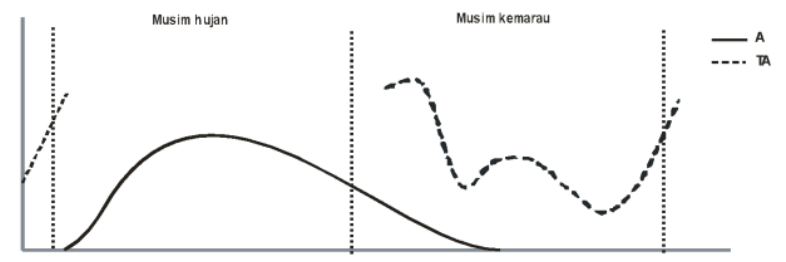

Okt Nov Des Jan Peb mar Apr Mei Juni Jul Agt Sep Okt Nov

Figure 3. Dynamical Patterns of $\mathrm{Fe}^{2+}$ solubility in the soil at natural condition (A) [5] and area with a one-way water system (TA) [14].

\subsection{Exchangeable Base Level}

As explained above that acid sulfate soil reclamation has caused a decrease in soil $\mathrm{pH}$. In very acidic soil conditions, Aluminum and $\mathrm{Fe}$ become more soluble so that they can push base cations from the surface of the sorption (Fig. 4). The reclamation of acid sulfate soils in Central Kalimantan has increased the solubility of Al [10]. Al is the dominant cation in raised bed soil [15]. Base cations separated from the site of sorption and in the soil solution are more susceptible to leaching into the lower layers and carried into the water, along with the movement of groundwater through the channels that have been made.

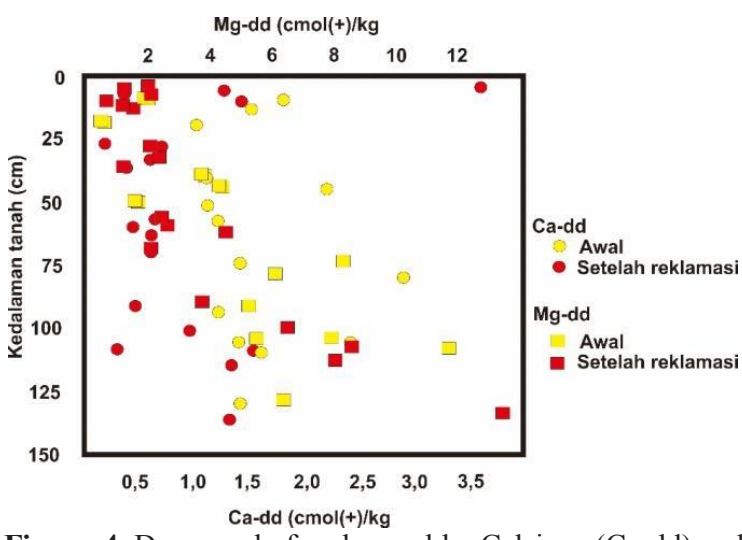

Figure 4. Decreased of exchangeable Calcium (Ca-dd) and exchangeable Magnesium (Mg-dd), caused by land reclamation [10].

\section{Mitigation Technology to Prevent Negative Impact From Reclamation}

Some components of land management technology must be applied to approach positive expectations in land reclamation of acid sulfate soils, such as an appropriate water management system, ameliorant, use of adaptive varieties, and optimum fertilization technology.

\subsection{Appropriate water management system}

Generally, the main problem in acid sulfate soil for agricultural purposes is the high acidity and high metal concentrations in the soils. This problem is caused by the oxidation of sulfidic material. Pyrite is oxidized because of its interaction with oxygen. Inundation is the only way to surely cut oxygen supply so pyrite oxidation does not occur [16]. Whereas prevention of pyrite oxidation by $\mathrm{Fe}^{3+}$ can be done by reducing reactivity and slowing down the rate of $\mathrm{Fe}^{3+}$ production, through the addition of ameliorant which can complex $\mathrm{Fe}^{3+}$ and thiobacillus bacteria. The basic principle for reducing the negative effects of pyrite oxidation is to wash away the acidity resulting from pyrite oxidation that has occurred [8]. There was an improvement in soil and water $\mathrm{pH}$ in the land after 5 years of inundation which took into account water quality [17].

It is very important to maintain the groundwater level above the sulfidic material layer, but the water used to irrigate must not stagnate for too long without flowing. So water irrigation (flooding) must be done intermittently at appropriate time intervals. Water that inundates acid sulfate soils contains more sources of soil acidity and other metals that have the potential to poison plants.

The one-way water system is a water management technology in tidal land that utilizes relatively better water quality at high tide to inundate the soil for some time and then releases it through drainage channels. Water only flows in through the inlet and then exits through other channels. To limit the direction of the water's flow, at each entrance and drainage channel is installed a special door that will open automatically driven by the flow of water (both at high tide and low tide). Application of one-way water system can improve soil chemical properties by increasing soil $\mathrm{pH}$ from 4.2 to 5.4 and $\mathrm{Fe}^{2+}$ concentration decreasing from 160 to 72 $\mathrm{ppm}$, so as increasing rice yield to $6.26 \mathrm{t} / \mathrm{ha}[18]$.

\subsection{Lime as Ameliorant}

One way to improve the quality of acid sulfate soil is lime application. Lime neutralizes acidity in soil and water, due to the oxidization of sulfidic materials. The application of lime causes soil $\mathrm{pH}$ to increase so that $\mathrm{Al}$ and $\mathrm{Fe}$ sedimented. If the type of lime given is in the form of dolomite, soil sorption will be filled with $\mathrm{Ca}$ and $\mathrm{Mg}$ ions so that the next reaction that occurs is an increase in the availability of $\mathrm{Ca}$ and $\mathrm{Mg}$, as illustrated in the following equation.

$$
\mathrm{H}_{2} \mathrm{SO}_{4}+\mathrm{CaCO}_{3}+\mathrm{H}_{2} \mathrm{O} \rightarrow \mathrm{CaSO}_{4}+2 \mathrm{H}_{2} \mathrm{O}+\mathrm{CO}_{2}
$$

Lime application dosages vary from hundreds of kilograms to tens of tons. It depends on the purpose of lime application. The addition of $4-6$ tons of lime to fulfill the growing needs of rice [19]. Whereas for land 
remediation, 4-6 tons of lime is categorized as very low, because this amount is not able to neutralize the acidity that arises due to oxidation of sulfidic material. 15-20 t $\mathrm{ha}^{-1}$ of lime is needed to achieve optimal conditions for plant growth [20]. The need for lime can even reach 30 tons/ha to neutralize the acidity of $1 \%$ oxidized sulfur [16].

\subsection{Utilization of organic materials}

The addition of organic material is often associated with efforts to control metals that are toxic to plants and increase nutrient availability, but in reality, the application of organic matter can also acidify the soil and increase $\mathrm{Fe}^{2+}$ solubility if not managed appropriately. Organic acid from the decomposition of relatively fresh organic material mainly in the form of acetic acid $\left(\mathrm{CH}_{3} \mathrm{COOH}\right)$ which can increase soil acidity [21]. Many types of researches have proven that organic matter increases soil pH (Fig. 5 A) or vice versa (Fig. 5 B). It is certainly understandable because one of the changes in soil $\mathrm{pH}$ is determined by the quality and quantity of organic matter supplied. The quality of organic matter has an important role in the direction of changes in soil $\mathrm{pH}$ and determines the rapid or slow recovery of soil $\mathrm{pH}$ after pyrite oxidation [22, 23]. Organic materials that can be given to increase soil $\mathrm{pH}$ are organic materials that have a low-medium $\mathrm{C} / \mathrm{N}$, especially in reducing conditions.

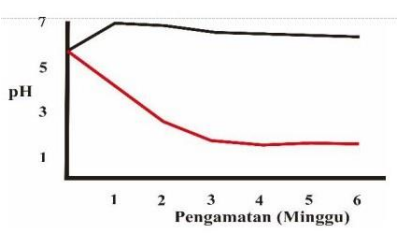

B

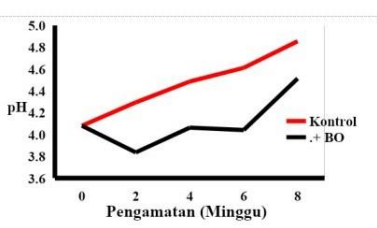

Figure 5. The effect of organic material quality on the dynamics of $\mathrm{pH}$ changes in acid sulfate soils $[2,22]$.

The decomposition of organic material in the early stages produces a lot of acetic acids. The oxidation of acetic acid always coincides with the reduction of $\mathrm{Fe}^{3+}$ [24]. Besides, the process of Fe chelating by organic acids resulting from the initial decomposition has not yet taken place optimal because organic acids which have a large chelating capacity towards Fe are organic acids which have large molecular weights, such as humic acid and fulvic acid. Humic acid and fulvic acid are very reactive because they contain total acidity about 500 $900 \mathrm{meq} 100 \mathrm{~g}^{-1}$ and $1400 \mathrm{meq} 100 \mathrm{~g}^{-1}$, respectively [25]. These organic acids are mainly produced by organic substances that are further humified.

Rice straw as the main source of organic material in rice cultivation of acid sulfate soils can be used to improve the characters of acid sulfate soils, but the straw must be composted before application. This method is more profitable because we have returned the nutrients present in rice straw to the land, about $5-8 \mathrm{~kg} / \mathrm{ha} \mathrm{N}, 0.7-1.2$ $\mathrm{kg} / \mathrm{ha} \mathrm{P}$, and $12-17 \mathrm{~kg} / \mathrm{ha} \mathrm{K}$ for every one ton of hay, indirectly [19].

\subsection{Use of Adaptive Varieties}

Rice is one of the suitable crops to be cultivated in acid sulfate soils. It mainly consists of long-lived (around 8 months) local rice varieties. These varieties have strong adaptability and tolerance to soil biophysical constraints, but its production is only around $2-3 \mathrm{t} / \mathrm{ha}$. To increase land productivity, one approach that can be taken to minimize the negative impact of acid sulfate soil reclamation is to plant adaptive high yielding varieties. Some of the adaptive varieties in acid sulfate soils are Margasari, Batanghari, Kapuas, and Inpara. Nevertheless, these varieties have different tolerances because they are greatly influenced by the parent's characters. The Margasari variety from Kalimantan is known to have a higher tolerance than the Batanghari variety from Sumatra, which is produced from the environment of the South Sumatra Region.

\subsection{Optimum Fertilization Technology}

The fertility status of acid sulfate soils, both before and after reclamation, is classified as very low. The addition of fertilizer is usually largely lost and strongly fixed by the soil component. Fertilization is needed to meet the needs of plant nutrients. Superphosphate fertilizers, when given to the soil, are fast release, but most of these fertilizers are lost due to water movement. One strategy to overcome this matter is determining the right way and timing of fertilizer application. To reduce $\mathrm{P}$ fixation by the soil component, each dose of fertilizer in one planting season should be given twice (split) before planting and then 4 - 5 weeks after planting. Meanwhile, to reduce the potential loss of fertilizer due to water movement, fertilizer should be given after changing the water in the rice fields, meaning that the time of planting and fertilizing must be adjusted to the time of the tide.

Another P fertilization strategy is the application of natural phosphate. Natural phosphate fertilizer is a mineral that contains calcium phosphate in the form of apatite $\left\{\mathrm{Ca}_{10}\left(\mathrm{PO}_{4}\right)_{6} \mathrm{~F}_{2}\right\}$. Aside from containing byproducts such as $\mathrm{Ca}$ and $\mathrm{Mg}$, this fertilizer is also slowrelease, making it suitable for acid soils. The acidity of acid sulfate soils is a key factor in the dissolution of $\mathrm{P}$ from natural phosphate [26]. The effect of natural phosphate depends on the quality and the reaction it caused. Natural phosphate has a long residual power for up to 3 years. Things to consider in the use of natural phosphate is its availability because generally, natural phosphate comes from areas far from the swamp environment.

\section{Conclusion}

Acid sulfate soil reclamation includes land clearing, land management, and water system development activities, aimed at increasing land productivity. Land management and construction of water irrigation systems, directly or 
indirectly, have caused oxidation or increased oxidation potential of sulfidic materials so that soil acidification occurs, the solubility of toxic metals increase, and leaching of base cations. The impact mainly occurred after the reclamation was carried out. These conditions will continue to occur for a long time if mitigation is not made. Several efforts can be made to mitigate acid sulfate soils such as appropriate water management, lime ameliorant, utilization of organic materials, application of adaptive varieties, and optimum fertilization technology. These mitigations must be carefully done so that they have a minimum negative impact on soil and crop.

\section{References}

1. J. Shamshuddin, A.E. Azura, M.A.R.S. Shazana, C.I. Fauziah, Q.A. Panhwar, U.A. Naher, Advances in Agronomy 124, 91-142, (Burlington, Academic Press, 2014)

2. A. Fahmi, B. Radjagukguk, B.H. Purwanto, J. of Trop. Soils, 14 (II) 119 - 125 (2009)

3. H. Subagyo, Karakteristik dan Pengelolaan Lahan Rawa, 1-22 (Bogor, Balai Besar Penelitian dan Pengembangan Sumberdaya Lahan Pertanian, 2006)

4. N.K. Fageria, G.D. Carvalho, A.B. Santos, E.P.B. Ferreira, A.M. Knupp, Comm. in Soil Science and Plant Analysis 42, 1913-1933 (2011)

5. K. Hanhart and D.V. Ni, Selected papers on the Ho Chi Minh City Symposium on Acid Sulphate Soils 53, (International Institute for Land Reclamation and Improvement, Wageningen, 1993)

6. O. Husson, M.T. Phung, M.E.F Van Mensvoort, Agric. Water Management J., 45, 127-143 (2000)

7. N. Van Breemen, Soil Sci. Soc. Amer. Proc., 39 (6), 1153-1157 (1975)

8. W.S. Hicks, G.M. Bowman R.W. Fitzpatrick, Australian J. of Soil Research, 47, 137-153 (2009)

9. R.W. Fitzpatrick, B.P. Thomas, R.H. Merry, S. Marvanek, Acid Sulfate Soils in Barker Inlet and Gulf St. Vincent Priority Region 35/08 (Australia, CSIRO, 2008)

10. M. Anda and A.B. Siswanto, 17 the World Cong. of Soil Science Symp. Thailand 63 (144), 1-14 (2002)

11. P.H. Verburg, Morphology and genesis of soils and evaluation of the side effects of a new canal in an acid sulfate soil area, Plain of Reeds, Vietnam
(Thesis, Wageningen Agricultural University, Netherlands, unpublished, 1994)

12. C. Blodau, Aquat. Sci. 66 47-59 (2004)

13. F.N. Ponnamperuma, Behavior of minor elements in paddy soils. IRRI Res. Paper Series, 15 (1977)

14. A. Jumberi, A. Fahmi, A. Susilawati, Prosiding Seminar Nasional Sumber Daya Lahan Pertanian. Bogor, 14 - 15 September 2006, 305 - 314 (2007)

15. G. Sterk, Selected papers on the Ho Chi Minh City Symposium on Acid Sulphate Soils, 53, 241-246 (International Institute for Land Reclamation and Improvement, Wageningen, 1993)

16. N. Van Breemen, Selected papers on the Ho Chi Minh City Symposium on Acid Sulphate Soils, 53, 391-402 (International Institute for Land Reclamation and Improvement, Wageningen, 1993)

17. S.G. Johnston, R.T. Bush, L.A. Sullivan, E.D. Burton, D. Smith, M.A. Martens, A.E. McElnea, C.R. Ahern, B. Powel, L.P. Stephens, S.T. Wilbraham, S. Van Heel, Estuarine, Coastal, and Shelf Science 81, 257-266 (2009)

18. I.P.G. Widjaja-Adhi and T. Alihamsyah, Prosiding Seminar Nasional dan Pertemuan Tahunan Komisariat Daerah Himpunan Ilmu Tanah, 51-72 (1998)

19. A. Dobermann and T. Fairhurst, Rice; Nutrient Disorders and Nutrient Management (Makati City, IRRI, 2000)

20. C.J.M. Konsten and M. Sarwani, Papers Workshop on Acid Sulphate in The Humid Tropics, 30-47 (AARD-LAWOO, Bogor, 1990)

21. K.H. Tan, Interaksi Mineral Tanah dengan Organik Alami dan Mikroba, 1-40 (Gadjah Mada University Press, 1997)

22. C. Yuan, L.M. Mosley, R. Fitzpatrick, P. Marschner, Geoderma 276, 26-32 (2016)

23. A. Kölbl, P. Marschner, R. Fitzpatrick, L. Mosley, and I. Kögel-Knabner, Geoderma 308, 350-362 (2017)

24. K. Kyuma, Paddy Soil Science (Melbourne, Australia, 2004)

25. M. Eltantawy and M Baverez, Soil Sci. Soc. of Am. J. 42, $903-905$ (1978)

26. S. Yampracha, T. Attanandana, A. Sidibe-Diarra, and R.S. Yost, Soil Sci. Soc. Am. J. 69, 2000-2011 (2005) 